\title{
TWO CANINE TOOTH SUPPORTED OVERDENTURE WITH READY-MADE ATTACHMENTS (3 YEAR PROSPECTIVE STUDY)
}

\author{
Ehab A. Elsaih* and Bassant Mowafey**
}

\begin{abstract}
Purpose: This study aimed to disclose the effect of two ready-made intra-radicular cemented attachments on abutment teeth periodontium of two canine tooth supported mandibular overdenture in 3 years study period.

Materials and Methods: Ten patients with edentulous maxilla \& a mandibular arch with only two canines remaining were selected based on certain criteria. All patients received maxillary complete dentures and an attachment-retained mandibular overdenture (OD); 1) Group [A] received magnetic attachment-retained $\mathrm{OD}$, and 2) Group [B] received O-ring attachment-retained OD. Modified Gingival index (MGI), clinical attachment loss (CAL) and marginal bone changes (MBC) were investigated along a 3 years follow up period.
\end{abstract}

Results: MGI results showed no statistically significant difference both in inter \& intra group results. CAL results showed significant differences between successive periods of the same group with no difference between the two groups in comparable periods.

Comparison of $\triangle \mathrm{CAL}$ values between groups in comparable periods also showed no statistical difference, but the sum of $\triangle \mathrm{CAL}$ in all 3 years showed statistical difference. Comparison of $\Delta$ MBC values between groups in comparable periods showed statistical difference in the 2 nd \& 3rd follow-ups as well as in all 3 years combined. $\triangle \mathrm{MBC} \& \triangle \mathrm{CAL}$, showed a weak positive correlation coefficient 0.368 in group 1 , and a strong positive correlation 0.942 in group 2.

Conclusion: It can be concluded that the two canine supported mandibular overdenture, retained either by ball and socket or magnetic attachments, is an acceptable treatment modality with predictable clinical results from a periodontal point of view as long as hygiene measures were strictly followed.

KEYWORDS : Tooth supported overdenture, ready-made attachments, magnetic attachment, O-ring

* Associate Professor of Removable Prosthodontics, Department of Removable Prosthodontics, Faculty of Dentistry, Mansoura University, Egypt.

** Lecturer of Diagnosis and Oral Radiology, Oral Medicine, Periodontology, Diagnosis and Oral Radiology Department, Faculty of Dentistry, Mansoura University, Egypt. 


\section{INTRODUCTION}

The aim of a Prosthodontist is to preserve the remaining oral structures and to rehab the missing oral functions, aiming for patient welfare ${ }^{(1)}$.

These standards should be applied taking into consideration both patient economics and technical feasibility of each treatment modality as well as technical ease and serviceability ${ }^{(2)}$.

Dental implants current status and wide range use of implant-supported dentures had been proved scientifically to improve the wearer's quality of life ${ }^{(3,4)}$; however, the higher cost of treatment with implants in developing countries means that nonimplant dependent removable dentures continue to replace missing teeth in large sectors of elderly ${ }^{(5-7)}$.

Tooth-supported removable prosthesis is aimed basically to preserve jaw alveolar bone or to forestall bone resorption ${ }^{(8)}$ due to sharing of occlusal load perception ${ }^{(9)}$. Teeth abutments with proper distribution can enhance masticatory efficiency ${ }^{(10)}$ and mechanical prosthesis performance in the form stability and retention especially when attachments are included ${ }^{(11,12)}$.

Attachment retained tooth overdentures can preserve weak teeth, enhance the status of their periodontium and enable their positive sharing in maintaining physiologic occlusion ${ }^{(13,14)}$.

Based on interpreting previous clinical reports, some authors considered tooth overdentures with attachment similar to implant overdentures for nearly-edentulous or edentulous mandible ${ }^{(15,16)}$ and considered the implant-free prosthetic solutions as a high interest treatment modality ${ }^{(17)}$. While other reports presented it as a conservative approach to root preservation which is still valid ${ }^{(18)}$ and participates to enhance patient satisfaction and comfort ${ }^{(19)}$.

Tooth overdenture uses attachments to secure enough resistance to the prosthesis dislodgment during functioning ${ }^{(20)}$. Some stud attachments are popular as ball \& socket and magnets ${ }^{(21,22)}$. Ball \& socket is used to serve primarily for removable prosthesis retention and share in their stabilization ${ }^{(23,24)}$. Magnets in prosthodontics after the 1990s were subjected to many technological advancements. They are also popular especially in limited inter-arch distance cases due to their small size, strong constant retention and less lateral force transmission to natural abutment's periodontium ${ }^{(25-28)}$.

Ready-made version of tooth overdenture attachments with intra radicular posts is claimed notable for ease of use, time saving, acceptable performance, economics and satisfying clinical serviceability for patients and prosthodontist as well ${ }^{(29-31)}$.

The clinician's focal point for tooth-supported overdentures has been abutment loss ${ }^{(32)}$, carries risks (33) and periodontal considerations ${ }^{(34-36)}$. Recently, more attention was developed for the prosthetic care / quality of life equation ${ }^{(31,37-39)}$.

Ready-made intra-radicular attachments were not studied in clinical trials, regarding the clinical tissue health parameters.

Thus this study aimed to spotlight the effect of the use of two different ready-made attachments with intra-radicular posts (Ball and socket, and magnetic attachments) on the periodontium of natural abutments supporting mandibular overdentures, in terms of gingival health status, attachment level change and marginal bone level and their relation. To tests the null hypothesis that this treatment modality produces an acceptable clinical parameters outcome with no difference between either of the used attachment types.

\section{MATERIAL AND METHODS}

This work was according to ethical guide lines and had been approved by the local ethics committee, collage of dentistry, Mansoura University (A16060721), then each patient was informed about the treatment plane and follow up regime and asked to sign informed consent according to the approved regulations before clinical procedures. 


\section{Patient selection}

Ten patients were selected based on inclusion criteria $^{(40,41)}$, proved by clinical and radiographic examination, including; no systemic diseases affecting bone or gingival health, normal maxillomandibular relationship, a completely edentulous maxillary arch opposed by a mandibular arch with two canines remaining (figure 1a) with moderate mandibular residual ridge height, adequate inter-arch space ( $\geq 18 \mathrm{~mm}$ ) at vertical dimension of occlusion to house both the attachments and denture material, and acceptable canine status that clarified by; proper clinical crown size, proper root length ( $>12 \mathrm{~mm}$ ) invested in bone, periodontal status (not to exceed grade II mobility), proper root canal morphology (canals free from calcification), proper root cross section and proper crown/root ratio. Table 1 shows the clinical characteristics of the selected cases.

\section{Clinical \& prosthetic procedures}

After abutments' root canal treatment, coronal part was removed leaving $2 \mathrm{~mm}$ crown height, then sharp areas removed and access opening filled with temporary filling material. All classical complete denture procedures were carried out. All patients followed strict oral hygiene protocol to assure preprosthetic healthy abutment soft tissue ${ }^{(42,43)}$.
Patients were divided into two equal groups randomly; Group 1 received $1.8 \mathrm{~mm}$ ball and socket attachment (Rhein 83, Bologna, Italy), and group 2 received $1.2 \mathrm{~mm}$ magnetic attachment (Shanghai Carejoy Medical Co., Ltd).

Patient were recalled for attachment installation, the first supra-gingival preparation was refined to be $1 \mathrm{~mm}$ with platform parallel to the horizontal plane, second the post space prepared shorter $4-5 \mathrm{~mm}$ from the root apex (x-ray of pilot drill was used to assure the length). After drilling the space was cleaned using $0.2 \%$ chlorhexidine gluconate irrigation, finally the attachment post (according to the pre-planned group attachment type, either ball or magnet) was tried in place then cemented with resin cement (figure $2 \mathrm{a}, 3 \mathrm{a}$ ).

A rubber spacer (supplied with ball attachment) (figure $2 b$ ) or piece of rubber dam was 1-inch square cut was applied on the patrix. Then the attachment matrix were attached to the Patrix (figure 2b, 3b), then the intaglio surface of lower denture was checked in place (using pressure indicating paste) for pick up space availability., then attachments were picked up (using chair side acrylic resin in one side at a time) (figure $2 \mathrm{c}, 3 \mathrm{c}$ ), then the occlusion was checked for possible premature interferences or deflective contacts and the denture was delivered (figure 1b).

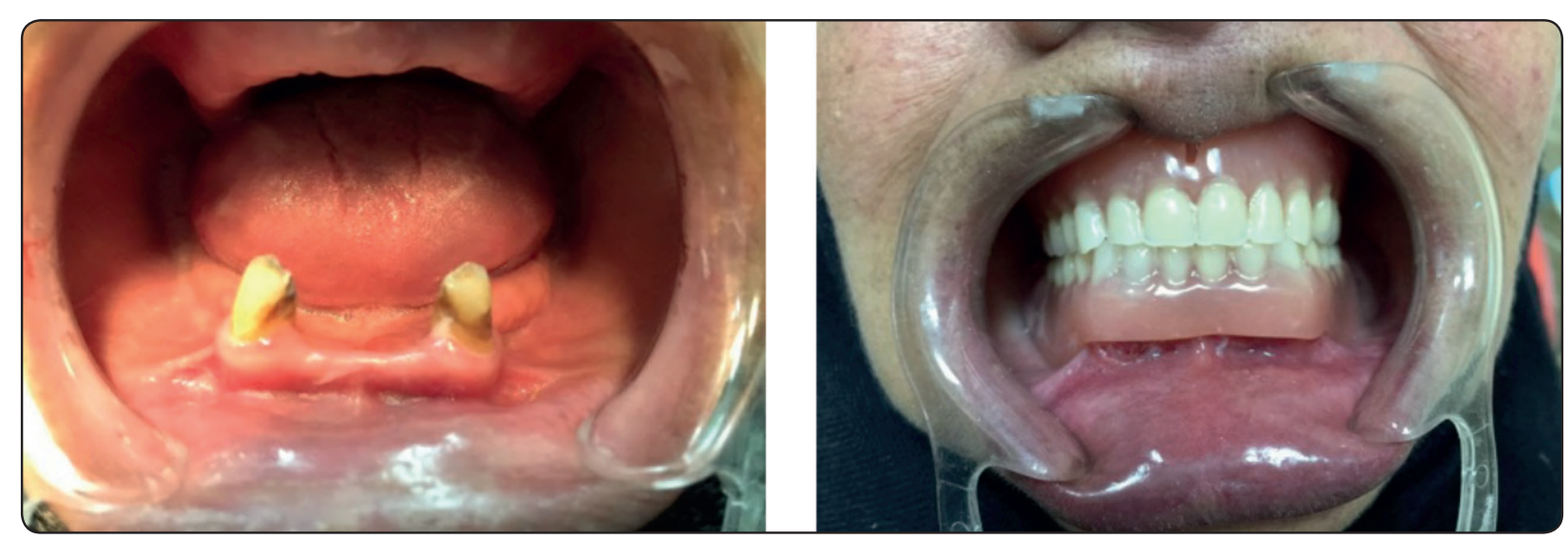

Fig. (1) a) Complete edentulous maxilla opposing mandibular partially edentulous arch with remaining two canines, b) Maxillary denture \& mandibular tooth supported overdenture after necessary adjustments \& occlusion refinement 
Primary preventive measures were instructed on daily bases, and secondary preventive measures on scheduled clinical follow up bases.

The clinical examination (soft tissue parameters) and radiographic examination was performed at base line (denture delivery), and each year in the three successive years after denture delivery.

\section{Clinical examination}

Two periodontal examiners collaborated to measure; 1$)$ the modified gingival index $(\mathrm{MGI})^{(44,45)}$ for all the teeth aspects of the same group (table 2), 2) the clinical attachment level (CAL) ${ }^{(46)}$ for each aspect of the abutments (the attachment level relative to the occlusal preparation margin of abutments) and the mean of the same site of all abutments in each group (table 3 ). The change in CAL was also calculated and tabulated (figure 4) (table 4).

\section{Radiographic examination}

Rubber base was used to form a stent for the X-ray holder (Kerr, Orange, CA, USA) to avoid bending or altering the angulation of the film and a $2 \mathrm{~mm}$ metal ball was embedded in the stent. All images obtained through long-cone paralleling technique using size $1(40 \times 24 \mathrm{~mm})$ photo-stimulable phosphor plate film (APIXIA® PSP Digital Imaging, Apixia Corp. United States) with exposure parameters of $10 \mathrm{~mA}, 70 \mathrm{kVp}$, and $0.16 \mathrm{~s}$ (figure 5a).

The digital software (CorelDraw ${ }^{\circledR}$ 10, Kodak Digital Science) was used to calculate the marginal bone level according to Preus et al (47) (figure 5b). Using the magnification error calculated from the metal ball known dimensions, the change in the bone level in each year was calculated and tabulated. The mesial and distal changes of the two abutments were gathered and the average of the 4 measurements was used.

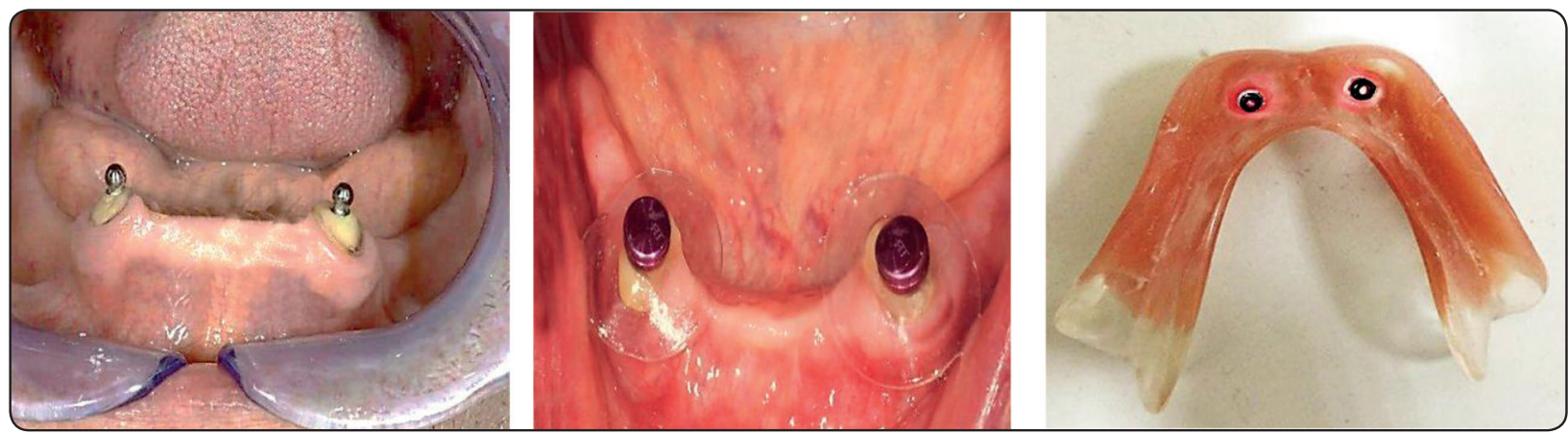

Fig. (2) a) Two ready-made ball attachment cemented intra radicular in each canine, b) metal socket with O-ring attachment before direct pick up procedure, with clear nylon spacer in between, c) O-ring attachments in denture intaglio surface.



Fig. (3) a) Two ready-made magnetic keeper cemented intra radicular in each canine, b) Magnetic attachments attached to its keepers, c) magnetic attachments in denture intaglio surface. 


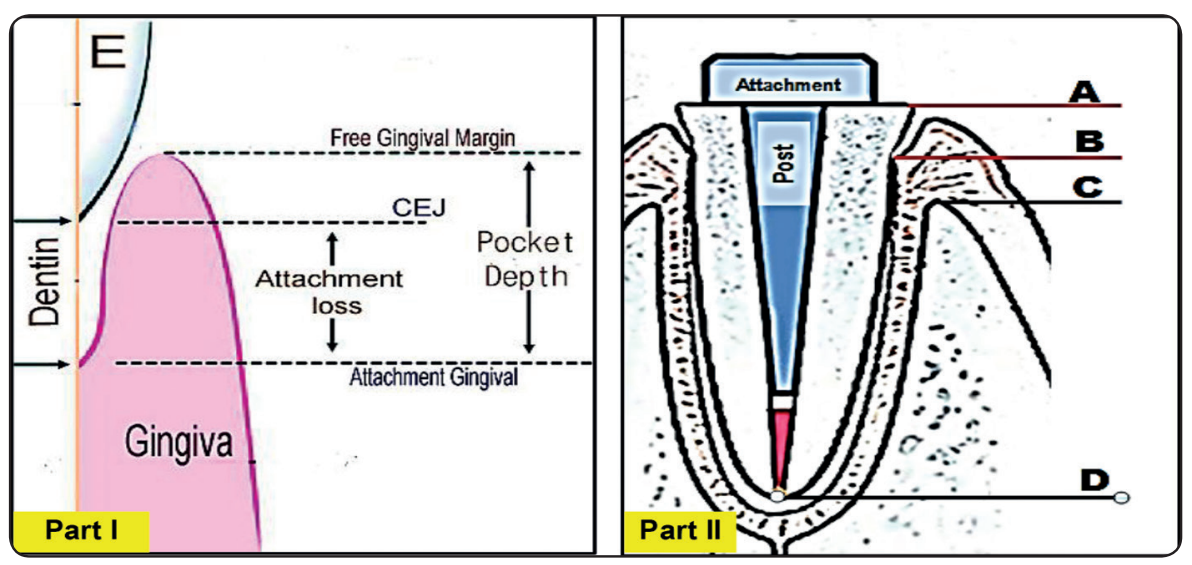

Fig. (4) Part I show; the anatomical landmarks used for attachment loss calculations, while part II show; the used landmarks for study cases, A) Tooth superior prepared surface, B) Attachment Epithelium, C) Marginal Alveolar bone, D) Root apex.

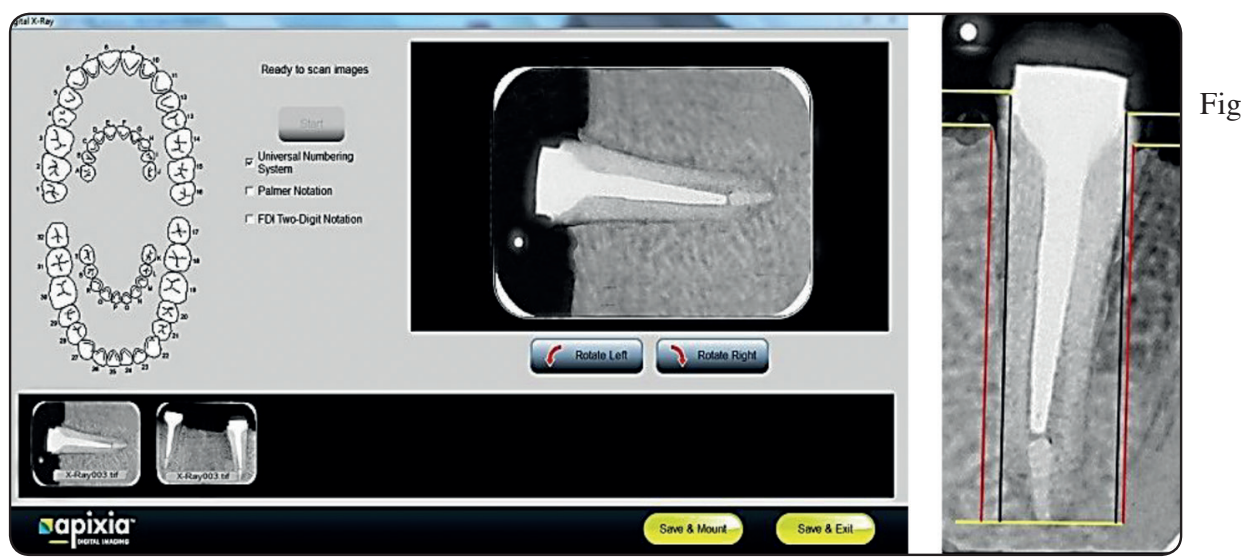

Fig. (5) a) Show the digital radiographic image of abutment/s, b) Show lines traced on radiograph to calculate the MBC.

\section{Statistical analysis}

Descriptive and inferential statistics were calculated using IBM ${ }^{\circledR}$ SPSS ${ }^{\circledR} \quad 25$. Levene's test was used for homogeneity of variances at significance-level P>0.05, and Shapiro-Wilk test used for normal distribution at significance-level $\mathrm{P}>0.05$. For normally distributed parametric data the independent variable t-test was used to compare the two groups at different periods while ANOVA was used to compare the difference within the group along the different periods. For nonparametric data the Friedman's test was used to compare change for different periods in same group \& the MannWhitney U test was used to compare different groups at different study periods. Dependent Samples T test was used to compare $\triangle \mathrm{CAL}$ and $\triangle \mathrm{MBC}$ while Pearson Correlation Coefficient (3 decimals) was used to calculate the correlation between patient's $\Delta$ $\mathrm{CAL}$ and $\triangle \mathrm{MBC}$ after 3 years study period

\section{RESULTS}

All patients attended the scheduled follow-up visits with no dropout.

Descriptive statistics for MGI, CAL, CAL, and $\triangle \mathrm{MBC}$ in both groups were presented in table 2,3, and 4.

A comparison of the mean MGI values showed no statistically significant difference between different follow-up periods within the group and between the two groups (table 2).

A comparison of the mean CAL values between different follow-up periods within the group showed significant differences for both groups, while a comparison between the groups showed insignificant differences in all study follow-up periods (table 3 ).

A comparison of the $\triangle \mathrm{CAL}$ values between the groups showed insignificant differences in each 
of the follow-up periods independently, however significance was evident between the two groups when changes in CAL of all three years were combined.

Comparison between groups of the $\triangle \mathrm{MBC}$ values showed significant differences in the 2 nd and the 3rd follow-up periods and for the changes in the three years combined (table 4).
Although the calculated Pearson correlation coefficient between values of the $\triangle \mathrm{CAL}$ and the $\triangle \mathrm{MBC}$ after 3 years, showed technically a weak positive correlation $(\mathrm{R}=0.368)$ and a strong positive correlation $(\mathrm{R}=0.942)$ for group 1 and group 2 respectively, the relationship between each variable in between the two groups for 3 years follow-up period was 0.9707 , and 0.9986 for $\Delta \mathrm{CAL}$, and $\Delta$ MBC respectively (table 5).

Table (1) show the clinical characteristics of the selected cases.

\begin{tabular}{|c|c|c|c|}
\hline Criteria & $\begin{array}{c}\text { Group } 1 \\
\overline{\mathrm{x}} \pm \mathrm{SD}\end{array}$ & $\begin{array}{l}\text { Group } 2 \\
\overline{\mathrm{x}} \pm \mathrm{SD}\end{array}$ & $\begin{array}{l}\text { All patients } \\
\overline{\mathrm{x}} \pm \mathrm{SD}\end{array}$ \\
\hline Age of patient in years & $57.8 \pm 1.30$ & $57 \pm 0.71$ & $57.4 \pm 1.08$ \\
\hline Gender (male/ female) & $5 / 0$ & $5 / 0$ & $10 / 0$ \\
\hline Previous use of removable prosthesis (in years) & $6.80 \pm 2.17$ & $5.00 \pm 3.67$ & $5.9 \pm 2.99$ \\
\hline Abutment root length (invested in bone in $\mathrm{mm}$ ) & $13.90 \pm 0.18$ & $13.96 \pm 0.86$ & $1.93 \pm 0.64$ \\
\hline Previous root canal treatment & $1(20 \%)$ & $0(0 \%)$ & $1(10 \%)$ \\
\hline Presence of attrition facets $(0=\mathrm{No}, 1=$ yes $)$ & $0.60 \pm 0.55$ & $0.40 \pm 0.55$ & $0.50 \pm 0.53$ \\
\hline Grade of mobility $(0=$ No, $1=$ Grade $\mathrm{I}, 2=$ Grade II $)$ & $0.80 \pm 0.45$ & $0.40 \pm 0.55$ & $0.60 \pm 0.52$ \\
\hline Gingival index (GI) & $0.00 \pm 0.00$ & $0.00 \pm 0.00$ & $0.00 \pm 0.00$ \\
\hline Free gingival margin level to CEJ (above/below) & $1 / 4$ & 5 & $1 / 9$ \\
\hline
\end{tabular}

Table (2) : The mean modified gingival index "MGI" of all teeth aspects between different study periods and between different groups in same period.

\begin{tabular}{|c|c|c|c|c|}
\hline & $\begin{array}{c}\text { Mean MGI } \\
x^{-} \pm S D\end{array}$ & Difference from baseline & $\mathrm{P} 1$ & $\mathrm{P} 2$ \\
\hline \multicolumn{5}{|c|}{ Magnet retained group } \\
\hline Base line & $0.00 \pm 0.00$ & - & - & - \\
\hline $1^{\text {st }}$ year & $0.66 \pm 0.20$ & $0.66 \pm 0.20$ & NS & NS \\
\hline $2^{\text {nd }}$ year & $1.18 \pm 0.36$ & $1.18 \pm 0.36$ & NS & NS \\
\hline $3^{\text {rd }}$ year & $1.47 \pm 0.35$ & $1.47 \pm 0.35$ & NS & NS \\
\hline \multicolumn{5}{|c|}{ Ball retained group } \\
\hline Base line & $0.20 \pm 0.04$ & - & - & - \\
\hline $1^{\text {st }}$ year & $0.76 \pm 0.20$ & $0.56 \pm 0.20$ & NS & NS \\
\hline $2^{\text {nd }}$ year & $1.08 \pm 0.26$ & $0.88 \pm 0.26$ & $\mathrm{NS}$ & NS \\
\hline $3^{\text {rd }}$ year & $1.27 \pm 0.30$ & $1.07 \pm 0.30$ & NS & NS \\
\hline
\end{tabular}

$N=20$ (number of abutment teeth in each group) $-P$ is Significant when $\leq 0.05$ $(M G I)=$ Modified Gingival Index

$0=$ absence of inflammation;

$1=$ one portion mild inflammation or with slight changes in color and texture

2 = as the preceding criteria, in all portions

3 = moderate, bright surface inflammation, erythema, edema and/or hypertrophy

4 = severe inflammation: erythema, edema, hypertrophy or spontaneous bleeding,

P1 comparison to base line (Friedman's test) P2 comparison to same period in the other group (Mann Whitney U test) 
TABLE (3) The mean clinical attachment level "CAL" (in $\mathrm{mm}$ ) for different abutment teeth surface of all patients in different study periods

\begin{tabular}{|c|c|c|c|c|c|c|c|c|c|c|c|c|c|}
\hline & \multicolumn{3}{|c|}{ At base line } & \multicolumn{3}{|c|}{1 year } & \multicolumn{3}{|c|}{2 years } & \multicolumn{3}{|c|}{3 years } & \multirow{2}{*}{ o } \\
\hline $\begin{array}{c}\text { Tooth } \\
\text { surface }\end{array}$ & $\begin{array}{c}\text { Mean } \\
\text { (SD) }\end{array}$ & Min & Max & $\begin{array}{l}\text { Mean } \\
(\mathrm{SD})\end{array}$ & Min & Max & $\begin{array}{l}\text { Mean } \\
(\mathrm{SD})\end{array}$ & Min & Max & Mean(SD) & Min & Max & \\
\hline \multicolumn{14}{|c|}{ Magnetic retained group (G1) } \\
\hline Mid- mesial & $1.40 \pm 0.55$ & 1.00 & 2.00 & $1.80 \pm 0.45$ & 1.00 & 2.00 & $2.4 \pm 0.55$ & 2.00 & 3.00 & $2.80 \pm 0.45$ & 2.00 & 3.00 & $\mathrm{P} 1$ \\
\hline Mid- distal & $1.20 \pm 0.45$ & 1.00 & 2.00 & $1.40 \pm 0.55$ & 1.00 & 2.00 & $2.20 \pm 0.45$ & 2.00 & 3.00 & $2.60 \pm 0.89$ & 2.00 & 4.00 & $\mathrm{P} 1$ \\
\hline Mid-buccal & $1.40 \pm 0.55$ & 1.00 & 2.00 & $2.20 \pm 0.84$ & 1.00 & 3.00 & $2.60 \pm 0.55$ & 2.00 & 3.00 & $3.20 \pm 0.45$ & 3.00 & 4.00 & P1 \\
\hline Mid- lingual & $1.20 \pm 0.45$ & 1.00 & 2.00 & $1.80 \pm 0.84$ & 1.00 & 3.00 & $2.60 \pm 0.55$ & 2.00 & 3.00 & $3.00 \pm 0.71$ & 2.00 & 4.00 & $\mathrm{P} 1$ \\
\hline \multicolumn{14}{|c|}{ Ball retained group (G2) } \\
\hline Mid- mesial & $1.20 \pm 0.45$ & 1.00 & 2.00 & $1.80 \pm 0.84$ & 1.00 & 3.00 & $2.40 \pm 0.55$ & 2.00 & 3.00 & $2.80 \pm 0.84$ & 2.00 & 4.00 & $\mathrm{P} 1$ \\
\hline Mid- distal & $1.63 \pm 0.63$ & 1.00 & 2.00 & $1.80 \pm 0.45$ & 2.00 & 3.00 & $2.30 \pm 0.84$ & 2.00 & 3.00 & $2.60 \pm 0.89$ & 3.00 & 4.00 & $\mathrm{P} 1$ \\
\hline Mid-buccal & $1.55 \pm 0.53$ & 1.00 & 2.00 & $2.15 \pm 0.91$ & 1.00 & 3.00 & $2.80 \pm 0.70$ & 2.00 & 4.00 & $3.20 \pm 0.43$ & 3.00 & 4.00 & $\mathrm{P} 1$ \\
\hline Mid- lingual & $1.60 \pm 0.55$ & 1.00 & 2.00 & $2.20 \pm 0.84$ & 1.00 & 3.00 & $2.60 \pm 0.55$ & 2.00 & 3.00 & $3.00 \pm 0.71$ & 3.00 & 4.00 & $\mathrm{P} 1$ \\
\hline $\begin{array}{c}\text { Independent } \\
\text { t-test }\end{array}$ & NS & & & NS & & & NS & & & NS & & & \\
\hline
\end{tabular}

$N=$ Number of teeth investigated (20 teeth in 10 patents divided into two groups)

SD, standard deviation; min, minimum; max, maximum.

CAL measurements were made at the mid-point of surface

Tabulated values are the average CAL of specific surface of all patents' teeth at each time point.

Time point statistically significant difference is based on pairwise contrasts of each time point with the other using repeatedmeasures P1 = significant difference on repeated measurements, $P 2=$ significant difference between same period in different groups

Statistical results were adjusted to 2 decimals

TABLE (4) The mean change in clinical attachment level "CAL" of all teeth aspects (in $\mathrm{mm}$ ) and the mean change in abutment tooth marginal bone "MBC" of proximal aspects (in $\mathrm{mm}$ ) for the 1st , 2nd , 3rd year and whole 3 years after denture insertion in both groups:

\begin{tabular}{|c|c|c|c|c|}
\hline & $\begin{array}{c}\text { 1st year } \\
\overline{\mathbf{x}} \pm \mathbf{S D}\end{array}$ & $\begin{array}{c}\text { 2nd year } \\
\overline{\mathbf{x}} \pm \mathbf{S D}\end{array}$ & $\begin{array}{c}\text { 3rd year } \\
\overline{\mathbf{x}} \pm \mathbf{S D}\end{array}$ & $\begin{array}{c}\text { All 3 years } \\
\overline{\mathbf{x}} \pm \mathbf{S D}\end{array}$ \\
\hline $\boldsymbol{\Delta}$ CAL & & & & \\
\hline Magnet retained group & $0.50 \pm 0.12$ & $0.57 \pm 0.16$ & $0.43 \pm 0.05$ & $1.51 \pm 0.09$ \\
\hline Ball retained group & $0.58 \pm 0.01$ & $0.60 \pm 0.14$ & $0.53 \pm 0.012$ & $1.63 \pm 0.10$ \\
\hline Independent t-test & .052 & .093 & .144 & $.013^{*}$ \\
\hline $\boldsymbol{\Delta M B C}$ & & & & $2.82 \pm 0.42$ \\
\hline Magnet retained group & $0.93 \pm 0.23$ & $0.90 \pm 0.14$ & $0.88 \pm 0.25$ & $3.01 \pm 0.69$ \\
\hline Ball retained group & $1.18 \pm 0.30$ & $1.11 \pm 0.183$ & $1.01 \pm 0.46$ & $.010^{*}$ \\
\hline Independent t-test & .11 & $.000 *$ & $.001 *$ \\
\hline
\end{tabular}

$N=20$ (number of abutment teeth in each group). $\Delta$ is the difference between two periods measurements' means. *=Significant when $p \leq 0.05$ 
TABLE (5) Show the Pearson Correlation Coefficient for the patient's $\triangle \mathrm{CAL}$ and $\triangle \mathrm{MBC}$ after 3 years study period

\begin{tabular}{|c|c|c|c|}
\hline & $\boldsymbol{\Delta}$ CAL & $\Delta$ MBC & \\
\hline & $\overline{\mathrm{x}} \pm \mathrm{SD}$ & $\overline{\mathrm{x}} \pm \mathrm{SD}$ & $\mathrm{R}$ \\
\hline Group1 & $1.51 \pm 0.09$ & $2.82 \pm 0.42$ & 0.368 \\
\hline Group2 & $1.63 \pm 0.10$ & $3.01 \pm 0.69$ & 0.942 \\
\hline $\mathrm{R}$ & 0.9707 & 0.9986 & \\
\hline
\end{tabular}

$R=$ Pearson Correlation Coefficient (3 decimals)

\section{DISCUSSION}

From this study, the null hypothesis is accepted as the treatment modalities using ready-made intra radicular attachments (ball and socket or magnets) produced acceptable performance within this study parameters.

The continuous investigation of different treatment modalities outcome helps to judge their current status to assist a proper estimation of their clinical validity in relation to other modalities addressing the same clinical situation. In literature, the reports of overdenture usually address the abutment prognosis and the rate of abutment loss. Rare reports in 90s, 80s and earlier discussed the abutments in relation to gingival tissue health but with no interest in the type of attachment. No reports addressed the ready-made attachment in relation to their effect on tissue health parameters.

Patient selection and inclusion criteria included; 1) adequate inter-arch space to provide enough room for both attachment and prosthesis ${ }^{(48)}, 2$ ) a good canine abutment root status as regards intraradicular anatomy and external morphology to assure non complicated endodontics and proper load distribution ${ }^{(49)}, 3$ ) adequate surrounding bone and healthy periodontium to assure the long term prognosis ${ }^{(50)}$.

Caries susceptibility for copping and noncopping tooth overdenture abutment is a common complication and it was reported by many authors
$(32,51)$. Caries was not the scope of this work but tooth surface discoloration was noted in some patients and was managed by prophylaxis and topical fluoride application and no caries lesion was detected on patients' scheduled follow-up.

Periodontal mobility was not to exceed Grade II (all cases were grade I or no mobility) upon patient inclusion which were changed after oral hygiene measures and crown reduction to no mobility. Change of crown/root ratio has a direct impact on decreasing mobility giving the abutment more resistance to oral forces ${ }^{(52,53)}$.

Also this was declared by other authors as Renner et al ${ }^{(54)}$, they pointed out that using retained roots as overdenture abutments can prevent mobility in $50 \%$ of roots, and improve periodontal status in $25 \%$ of roots. Crown reduction is also suggested to improve compromised abutment's periodontium by other researchers ${ }^{(18,55)}$. Mobility was not the scope of this work but no abutment mobility was detected on patients' scheduled follow-up.

The gingival inflammation is the first step in the periodontium affection dilemma especially when gingival inflammation fails to resolve and turn to become chronic ${ }^{(56)}$, Hence monitoring of gingival health is important to disclose the possibility and risk of inflammatory destruction of periodontal tissues ${ }^{(57)}$, and subsequent risk of abutment teeth eventual loss ${ }^{(58,59)}$.

The MGI is a subjective scale index that was believed to increase the sensitivity of gingival scoring scale and be less aggressive by eliminating the bleeding on pressure maneuvers ${ }^{(45)}$. According to Lobene et al ${ }^{(60)}$, the MGI has a significant correlation with other indices that claimed more invasive as Gingival Index, Interdental Bleeding Index and Papillary Bleeding Index.

The results of this work showed a non-significant change in MGI within or between groups, which can be attributed to strict oral hygiene and regular 
follow-up. But the more important interpretation is the absence of active chronic inflammation during the study period.

Some authors considered CAL as a key element to represent and judge the health status of teeth/ abutments ${ }^{(43,61)}$, others suggested CAL strong relation to the tooth loss ${ }^{(62)}$, others considered that radiographic data is needed as a supplementary information to complement the probing data ${ }^{(63)}$ and others reported concordance in radiographic and attachment level change found in $82 \%$ of the sites examined ${ }^{(64,65)}$.

The results of CAL reflected a significant decrease of CAL for all successive periods in both groups with an insignificant difference after 3 years of study. The non-significant results of MGI over the follow-up periods combined with the significant change in CAL over the same periods in both groups may suggest minimal or no inflammatory origin of the change in CLA.

The results showed a reduction in both CAL and change in MBC by time which was significant when both groups were compared for the total 3 year period. Thus, the stresses transferred by loading the abutments may be claimed responsible for that. That was presented by authors as Reinhardt et al ${ }^{(66)}$ Reddy and Vandana ${ }^{(67)}$, they pointed out that the principal stresses on the periodontium on occlusal loading are maximum near the alveolar crest. Such stress generation was suggested to affect the integrity of the periodontal structures as a biologic reaction ${ }^{(68)}$ and even reducing alveolar bone heights ${ }^{\left({ }^{(6)}\right.}$.

The stress transition to the periodontium from direct occlusal loading through natural tooth, differs from the stress transition from artificial teeth and denture base to the periodontium through attachment. Besides, both used attachments offers innate stress reduction functionality ${ }^{(20,21,28,70,71,72)}$.

Also, according to Zhang $\mathrm{H}$. et al ${ }^{(73)}$, teeth loading should be discussed, taking into consideration that there is a difference between the maximum tooth stress (MTS) and maximum periodontal stress (MPS) and consequently they are not a cause and effect relationship. In addition, Fan and Caton ${ }^{(74)}$ concluded that occlusal forces is not related to gingival recession or loss of periodontal attachment.

It was reported that even the clinical inflammationfree periodontium, may suffer negative changes as CAL, possibly due to a combination of excessive force and frequency of mechanical stimulation with a potential bone loss especially in aging subjects ${ }^{(75,76)}$. It is important to consider the relation between periodontal ligament (PL) and alveolar bone, masticatory forces, aging. As the PL cells are involved in alveolar bone repair. That relation is affected or disturbed by loading and becomes irregular especially by aging ${ }^{(77)}$, reports specified a correlation between alveolar loss increases up to the age of 45 years, then a steady rate increase continued among individuals $\geq 50$ years ${ }^{(78)}$. This was emphasized on earlier reports that discussed a moderate loss of PL and alveolar bone as an aging natural consequence ${ }^{(79)}$. Discussing $\mathrm{CAL}$ and related $\mathrm{MBC}$ as a multifactorial situation is more logical because the non-inflammatory or stressinduced causes imply an oversimplification.

Generally speaking, ball attachment is of low bulk and allows free prosthesis movement (stress breaking action) that preserves their periodontium integrity ${ }^{\left({ }^{80}\right)}$. Ball group significant difference may be attributed to their design that offers prosthesis stabilization and retention ${ }^{(20,21)}$.

In this work the $\triangle \mathrm{CAL}$ and $\triangle \mathrm{MBC}$ showed a positive correlation in both groups especially in ball group. According to Odom \& Morrow ${ }^{(81)}$ the correlation coefficient interpretation is more significant in simple or multifactorial procedures. More +ve correlation in ball group means that the possibility of stress scenario is highly recommended. It is also worthy to mention that the recorded rate of $\triangle \mathrm{CAL}$ and $\triangle \mathrm{MBC}$ was in the acceptable range. 
A study reported inflammatory-origin $\triangle \mathrm{CAL}$ for 9 months follow-up as $1.03 \mathrm{~mm}, 0.357 \mathrm{~mm}$, $0.581 \mathrm{~mm}$ for sever, moderate and mild affected sites respectively ${ }^{\left({ }^{82}\right)}$. While another 5 year followup study reported an average annual CAL of $0.3 \pm$ $0.01 \mathrm{~mm}$ in healthy subjects where $\triangle \mathrm{CAL}$ increased rate with age (up to 40-49 years) and among males ${ }^{(83)}$. Schätzle et al ${ }^{\left({ }^{(8)}\right)}$ reported mean CAL in healthy subjects that range $0.02-0.1 \mathrm{~mm}$ annually with a continuous increase after the age of 40 years. Also a range of $0.36-0.38 \mathrm{~mm} /$ year was reported in periodontitis affected teeth ${ }^{(85)}$. While a systematic review of Needleman et al ${ }^{(86)}$ briefed a mean annual attachment loss in healthy periodontium $0.1 \mathrm{~mm} /$ year that increased in periodontitis up to $0.6 \mathrm{~mm} /$ year.

The limited sources addressing the CAL and MBC for tooth overdenture abutments, necessities a carful results interpretation ${ }^{(87,88,89)}$.

Early reports described the important relation between overdenture abutment position in their arches and their gingival health and pocket depth ${ }^{(90,91)}$. Morrow et al ${ }^{(92)}$ reported $9.0 \mathrm{~mm}$ increase in pocket depth over a 6month follow-up. Fenton and Hahn ${ }^{(93)}$ found insignificant change in pocket depth in comparison with control teeth group. Davis et al (94) reported $0.54 \mathrm{~mm}$ increase in the loss of width of the attached gingiva. Toolson et al ${ }^{(95,96)}$ reported in a 2 year study a minor change of $0.2 \mathrm{~mm}$ in pocket depth yearly and a mean gingival index of 1.6. Graser and Caton ${ }^{\left({ }^{97}\right)}$ reported $0.2 \mathrm{~mm}$ increase in pocket depth over 1 year follow up.

Change in CAL and MBC is a multifactorial problem and both the periodontal stress scenario and the inflammatory scenario were widely accepted in literature, but the MGI results direct attention to stress based understanding. The weak +ve correlation between CAL and MBL in the magnetic group may be suggestive to a load stress-based interpretation and understanding, as the magnets are known for lateral force dissipation ${ }^{(36,98)}$ so it is less vulnerable to transfer destructive forces to the periodontium. Control of oral hygiene may have limited the inflammatory background, but it cannot assure its absence even on subclinical pattern.

It is worthy to report the patient expressed satisfaction with the attachment retained prosthesis immediately after delivery, especially the stability in ball group and the self-alignment in magnetic group, that was also mentioned in other clinical reports ${ }^{25}$, $99,100,101)$. One patient complained of metallic taste in the magnetic group in the first 3 months after prosthesis delivery, and this was repeated when the magnet was replaced after 2 years of use.

\section{CONCLUSION}

In conclusion, the results suggested a relation between transmitted occlusal loading to the periodontium and the results of study parameters, but the strength of results should be carefully interpreted due to the small subject number. Although it could be concluded objectively that the two canine supported mandibular overdenture is an acceptable treatment modality.

Also, the impact of the two attachment types on the periodontium is acceptable. And according to the study criteria, no one type is preferred over the others. But the magnetic attachment seems preferred in terms of less effect on the periodontium and low profile.

This line of treatment may be suggested to offer predictable results, once the hygiene measures were followed to preserve periodontium health.

\section{Conflict of interest}

The author declare no conflict of interest.

\section{Financial disclosures}

The author declare that this work had no financial support from any governmental nor private foundation. 


\section{REFERENCES}

1. Atieh MA, Alsabeeha NH, Payne AG, Duncan W, Faggion CM, Esposito M. Interventions for replacing missing teeth: alveolar ridge preservation techniques for dental implant site development. Cochrane Database Syst Rev. 2015 May 28;2015(5):CD010176.

2. Krausch-Hofmann S, Cuypers L, Ivanova A, Duyck J. Predictors of Patient Satisfaction with Removable Denture Renewal: A Pilot Study. J Prosthodont. 2018;27(6):509516.

3. Eydecke G, Locker D, Awad MA, Lund JP, Feine JS. Oral and general health-related quality of life with conventional and implant dentures. Community Dent Oral Epidemiol. 2003;31:161-8.6.

4. Carlsson GE, Omar R. The future of complete dentures in oral rehabilitation. A critical review. J Oral Rehabil. 2010;37:143-56.

5. Uo HC, Kuo YS, Lee IC, Wang JC, Hsin YY. The association of responsiveness in oral and general health related quality of life with patients' satisfaction of new complete dentures. Qual Life Res. 2013;22:1665-74

6. Dhumal P. Attachment supported dentures. IOSR Journal of Dental and Medical Sciences. May 2019;18,5:72-76

7. Burns DR. The mandibular complete overdenture. Dent Clin North Am. 2004;48(3):603-vi.

8. Langer Y, Langer A. Root-retained overdentures: part II managing trauma between edentulous ridges and opposing dentition. J Prosthet Dent 1992; 67:77-81.

9. Carlsson GE. Implant and root supported overdentures - a literature review and some data on bone loss in edentulous jaws. J Adv Prosthodont. 2014;6(4):245-252.

10. Rissin L, House JE, Manly RS, Kapur KK. Clinical comparison of masticatory performance and electromyographic activity of patients with complete dentures, overdentures, and natural teeth. J Prosthet Dent 1978;39:508-11.

11. Walters RA. Design, preparation, and maintenance of overdenture abutments. Dent Clin North Am. 1990;34(4):631644.

12. Bassi F. Overdenture therapy and worst-case scenarios: alternative management strategies. Int $\mathrm{J}$ Prosthodont. 2007;20(4):350-353.

13. Fatalla AA, Song K, Du T, Cao Y. An in vitro investigation into retention strength and fatigue resistance of various designs of tooth/implant supported overdentures. J Huazhong Univ Sci Technolog Med Sci. 2012;32(1):124-129.

14. Schwindling FS, Dittmann B, Rammelsberg P. Doublecrown-retained removable dental prostheses: a retrospective study of survival and complications. J Prosthet Dent. 2014;112(3):488-493.

15. Al-Zubeidi MI, Payne AG. Mandibular overdentures: a review of treatment philosophy and prosthodontic maintenance. N Z Dent J. 2007;103(4):88-97.

16. Samra, R. K., Bhide, S. V., Goyal, C., \& Kaur, T. Tooth supported overdenture: a concept overshadowed but not yet forgotten!. Journal of Oral Research and Review 2015; $7(1): 16$.

17. Shetty O, Tolani P, Rathod A. Oral rehabilitation using customized intra-radicular Dalbo attachments. J Interdiscip Dentistry 2013;3:36-42

18. Bambara GE. The attachment-retained overdenture. N Y State Dent J. 2004;70(9):30-33.

19. Rinke S, Schneider L, Schulz X, Wiedemann V, Bürgers R, Rödiger M. Overdentures borne on less than four abutments with telescopic crowns: 5-year results of a retrospective clinical study. Clin Oral Investig. 2019;23(8):3153-3160.

20. The Glossary of Prosthodontic Terms: Ninth Edition. J Prosthet Dent. 2017;117(5S):e1-e105.

21. Kanathila, H., Doddamani, M. H., \& Pangi, A. An insight into various attachments used in prosthodontics: A review. International Journal of Applied Dental Sciences 2018; 4(4): 157-160.

22. Gillings BR, Samant A. Overdentures with magnetic attachments. Dent Clin North Am 1990;34:683-709.

23. Banton B, Henry MD. Overdenture retention and stabilization with ball-and-socket attachments: principles and technique. J Dent Technol. 1997 Sep;14(7):14-20.

24. Bansal S, Aras MA, Chitre V. Tooth Supported Overdenture Retained with Custom Attachments: A Case Report. J Indian Prosthodont Soc. 2014 Dec;14(Suppl 1):283-6.

25. Riley MA, Walmsley AD, Harris IR. Magnets in prosthetic dentistry. J Prosthet Dent. 2001; 86:137-42.

26. Walmsley AD. Magnetic retention in prosthetic dentistry. Dent Update. 2002;29(9):428-433.

27. Ohashi N, Koizumi H, Ishikawa Y, Furuchi M, Matsumura $\mathrm{H}$, Tanoue N. Relation between attractive force and keeper 
surface characteristics of iron-neodymium-boron magnetic attachment systems. Dent Mater J. 2007 May;26(3):393-400.

28. Gonda, T., \& Maeda, Y. Why are magnetic attachments popular in Japan and other Asian countries? Japanese Dental Science Review 2011; 47(2): 124-130.

29. Țâncu AM, Melescanu Imre M, Preoteasa CT, Preoteasa E. Therapeutical attitudes in tooth supported overdentures with ball attachements. Case report. J Med Life. 2014;7 Spec No. 4(Spec Iss 4):95-98.

30. Faraj AA, Faten SA, \& Rania AF. Comparative study between two types of attachments used for root-supported overdenture. Alexandria Dental Journal 2016; 41(1):12-19.

31. Nassar, H. I. (2016). Patient satisfaction of tooth supported overdentures utilizing ball attachments. Future Dental Journal 2016; 2(2): 70-73.

32. Mercouriadis-Howald A, Rollier N, Tada S, McKenna G, Igarashi K, Schimmel M. Loss of natural abutment teeth with cast copings retaining overdentures: a systematic review and meta-analysis. J Prosthodont Res. 2018 Oct;62(4): 407-415.

33. Ettinger RL, Jakobsen J. Caries: a problem in an overdenture population. Community Dent Oral Epidemiol. 1990 Feb;18(1):42-5.

34. Budtz-Jörgensen E. Effects of denture-wearing habits on periodontal health of abutment teeth in patients with overdentures. J Clin Periodontol. 1994 Apr;21(4):265-9.

35. Budtz-Jörgensen E. Prognosis of overdenture abutments in elderly patients with controlled oral hygiene. A 5 year study. J Oral Rehabil. 1995 Jan;22(1):3-8.

36. Ettinger RL, Qian F. Incidence of attachment loss of canines in an overdenture population. J Prosthet Dent. 2014 Dec;112(6):1356-63.

37. Dostálová $\mathrm{T}$, Radina $\mathrm{P}$, Seydlová $\mathrm{M}$, Zvárová J, Valenta Z. Overdenture - implants versus teeth - quality of life and objective therapy evaluation. Prague Med Rep. 2009;110(4):332-42.

38. Limpuangthip N, Somkotra T, Arksornnukit M. Modified retention and stability criteria for complete denture wearers: A risk assessment tool for impaired masticatory ability and oral health-related quality of life. J Prosthet Dent. 2018 Jul;120(1):43-49.

39. Scotti R, Melilli D, Pizzo G. Overdenture su denti naturali. Analisi dei vantaggi clinici [Overdenture supported by natural teeth: analysis of clinical advantages]. Minerva Stomatol. 2003 May;52(5):201-10. (Abstract).
40. Zamikoff II. Overdentures - theory and technique. J Am Dent Assoc. 1973 Apr;86(4):853-7.

41. Dhir, R. C. Clinical assessment of the overdenture therapy. The Journal of Indian Prosthodontic Society. 2005;5(4):187.

42. Albandar JM, Kingman A. Gingival recession, gingival bleeding, and dental calculus in adults 30 years of age and older in the United States, 1988-1994. J Periodontol. 1999 Jan;70(1):30-43.

43. Best AM, Burmeister JA, Gunsolley JC, Brooks CN, Schenkein HA. Reliability of attachment loss measurements in a longitudinal clinical trial. J Clin Periodontol. 1990 Sep;17(8):564-9.

44. Newbrun E. Indices to measure gingival bleeding. J Periodontol. 1996 Jun;67(6):555-61.

45. Lobene RR, Weatherford T, Ross NM, Lamm RA, Menaker L. A modified gingival index for use in clinical trials. Clin Prev Dent. 1986 Jan-Feb;8(1):3-6.

46. Michalowicz BS, Hodges JS, Pihlstrom BL. Is change in probing depth a reliable predictor of change in clinical attachment loss? J Am Dent Assoc. 2013 Feb;144(2):171-8.

47. Preus HR, Torgersen GR, Koldsland OC, Hansen BF, Aass AM, Larheim TA, Sandvik L. A new digital tool for radiographic bone level measurements in longitudinal studies. BMC Oral Health. 2015 Sep 8;15:107.

48. Ahuja S, Cagna DR. Classification and management of restorative space in edentulous implant overdenture patients. J Prosthet Dent. 2011 May;105(5):332-7.

49. Kainose K, Nakajima M, Foxton R, Wakabayashi N, Tagami J. Stress distribution in root filled teeth restored with various post and core techniques: effect of post length and crown height. Int Endod J. 2015 Nov;48(11):1023-32.

50. Simon JH, Glick DH, Frank AL. The relationship of endodontic-periodontic lesions. J Endod. 2013 May; 39(5):e41-6.

51. Lord J, Teel S. The overdenture: patient selection, use of copings and follow-up reevaluation. J Prosthet Dent 1974;32:41-51.

52. Grossmann Y, Sadan A. The prosthodontic concept of crown-to-root ratio: a review of the literature. J Prosthet Dent. 2005 Jun;93(6):559-62.

53. Hegde V, Acharya, SR, Singh GP. Validity of crown-toroot ratio as a prognostic tool in clinical practice. Journal of Evolution of Medical and Dental Sciences. 2014;3(74): 15589-15600. 
54. Renner RP, Gomes BC, Shakun ML, Baer PN, Davis RK, Camp P. Four-year longitudinal study of the periodontal health status of overdenture patients. J Prosthet Dent. 1984;51(5):593-598.

55. Guttal SS, Tavargeri AK, Nadiger RK, Thakur SL. Use of an implant o-ring attachment for the tooth supported mandibular overdenture: a clinical report. Eur J Dent. 2011;5(3):331-336.

56. Cekici A, Kantarci A, Hasturk H, Van Dyke TE. Inflammatory and immune pathways in the pathogenesis of periodontal disease. Periodontol 2000. 2014 Feb;64(1):57-80.

57. Yang Y, Huang Y, Li W. Autophagy and its significance in periodontal disease. J Periodontal Res. 2021 Jan;56(1):18-26.

58. Ettinger RL, Qian F. Abutment tooth loss in patients with overdentures. J Am Dent Assoc. 2004 Jun;135(6):739-46; quiz 795-6.

59. Fenlon MR. Periodontal disease, periapical lesions and caries were, in that order, the causes of overdenture abutment loss. J Evid Based Dent Pract. 2005 Jun;5(2):94-5.

60. Lobene RR, Mankodi SM, Ciancio SG, Lamm RA, Charles $\mathrm{CH}$, Ross NM. Correlations among gingival indices: a methodology study. J Periodontol. 1989 Mar;60(3):159-62.

61. Gilbert GH, Shelton BJ, Chavers LS, Bradford EH Jr. Predicting tooth loss during a population-based study: role of attachment level in the presence of other dental conditions. J Periodontol. 2002 Dec;73(12):1427-36.

62. Hausmann E, Allen K, Norderyd J, Ren W, Shibly O, Machtei E. Studies on the relationship between changes in radiographic bone height and probing attachment. J Clin Periodontol. 1994 Feb;21(2):128-32.

63. Brägger U. Radiographic parameters: biological significance and clinical use. Periodontol 2000. 2005;39:73-90.

64. Cury PR, Araújo NS, Bowie J, Sallum EA, Jeffcoat M. The relationship between radiographic and clinical parameters in periodontal maintenance in class II furcation defects. Braz Oral Res. 2004 Apr-Jun;18(2):116-20.

65. Desai SR, Shinde HH. Correlation of interdental and interradicular bone loss in patients with chronic periodontitis: a clinical and radiographic study. Niger J Clin Pract. 2012 Apr-Jun;15(2):125-31.

66. Reinhardt RA, Pao YC, Krejci RF. Periodontal ligament stresses in the initiation of occlusal traumatism. J Periodontal Res. 1984 May;19(3):238-46.

67. Reddy MK, Vandana KL. Three-dimensional finite element analysis of stress in the periodontium. J Int Acad Periodontol. 2005 Oct;7(4):102-7.
68. Poiate IA, de Vasconcellos AB, de Santana RB, Poiate E. Three-dimensional stress distribution in the human periodontal ligament in masticatory, parafunctional, and trauma loads: finite element analysis. J Periodontol. 2009 Nov;80(11):1859-67.

69. Geramy A, Faghihi S. Secondary trauma from occlusion: three-dimensional analysis using the finite element method. Quintessence Int. 2004 Nov-Dec;35(10):835-43.

70. Suzuki Y, Ohkubo C, Kurtz KS. Clinical application of stress-breaking ball attachment for implant overdenture. J Prosthodont Res. 2013 Apr;57(2):140-4.

71. Ebadian B, Talebi S, Khodaeian N, Farzin M. Stress analysis of mandibular implant-retained overdenture with independent attachment system: effect of restoration space and attachment height. Gen Dent. 2015 Jan-Feb;63(1):61-7.

72. Khurana N, Rodrigues S, Shenoy S, Saldanha S, Pai U, Shetty T, N S, Mahesh M, Hegde P. A Comparative Evaluation of Stress Distribution with Two Attachment Systems of Varying Heights in a Mandibular Implant-Supported Overdenture: A Three-Dimensional Finite Element Analysis. J Prosthodont. 2019 Feb;28(2):e795-e805.

73. Zhang H, Cui JW, Lu XL, Wang MQ. Finite element analysis on tooth and periodontal stress under simulated occlusal loads. J Oral Rehabil. 2017 Jul;44(7):526-536.

74. Fan J, Caton JG. Occlusal trauma and excessive occlusal forces: Narrative review, case definitions, and diagnostic considerations. J Periodontol. 2018 Jun;89 Suppl 1:S214-S222.

75. Borges CD, Ricoldi MS, Messora MR, Palioto DB, Souza SLS, Novaes Júnior AB, Taba M Jr. Clinical attachment loss and molecular profile of inflamed sites before treatment. J Appl Oral Sci. 2019 Sep 9;27:e20180671.

76. Chapple ILC, Mealey BL, Van Dyke TE, Bartold PM, Dommisch H, Eickholz P, Geisinger ML, Genco RJ, Glogauer M, Goldstein M, Griffin TJ, Holmstrup P, Johnson GK, Kapila Y, Lang NP, Meyle J, Murakami S, Plemons J, Romito GA, Shapira L, Tatakis DN, Teughels W, Trombelli L, Walter C, Wimmer G, Xenoudi P, Yoshie H. Periodontal health and gingival diseases and conditions on an intact and a reduced periodontium: Consensus report of workgroup 1 of the 2017 World Workshop on the Classification of Periodontal and Peri-Implant Diseases and Conditions. J Periodontol. 2018 Jun;89 Suppl 1:S74-S84.

77. Repeke CE, Cardoso CR, Claudino M, Silveira EM, Trombone AP, Campanelli AP, Silva JS, Martins W Jr, Garlet GP. Non-inflammatory destructive periodontal disease: a clinical, microbiological, immunological and genetic investigation. J Appl Oral Sci. 2012 Feb;20(1):113-21. 
78. Huttner EA, Machado DC, de Oliveira RB, Antunes AG, Hebling E. Effects of human aging on periodontal tissues. Spec Care Dentist. 2009 Jul-Aug;29(4):149-55.

79. Burt BA. Periodontitis and aging: reviewing recent evidence. J Am Dent Assoc. 1994 Mar;125(3):273-9.

80. Mensor MC. Removable partial overdentures with mechanical (precision) attachments. Dent Clin North Am. 1990 Oct;34(4):669-81.

81. Odom LR, Morrow Jr JR. What's this R? A correlational approach to explaining validity, reliability and Objectivity coefficients. Measurement in Physical Education and Exercise Science. 2006;10(2):137-145

82. Machtei EE, Norderyd J, Koch G, Dunford R, Grossi S, Genco RJ. The rate of periodontal attachment loss in subjects with established periodontitis. J Periodontol. 1993 Aug;64(8):713-8.

83. Haas AN, Gaio EJ, Oppermann RV, Rösing CK, Albandar JM, Susin C. Pattern and rate of progression of periodontal attachment loss in an urban population of South Brazil: a 5-years population-based prospective study. J Clin Periodontol. 2012 Jan;39(1):1-9.

84. Schätzle M, Löe H, Lang NP, Heitz-Mayfield LJ, Bürgin W, Anerud A, Boysen H. Clinical course of chronic periodontitis. III. Patterns, variations and risks of attachment loss. J Clin Periodontol. 2003 Oct;30(10):909-18.

85. Alotaibi A, Modesto A, Vieira AR. Non-surgical periodontal therapy impact on progression of chronic periodontitis and prevention of further tooth loss. J Oral Med. 2018;2(1):3.

86. Needleman I, Garcia R, Gkranias N, Kirkwood KL, Kocher T, Iorio AD, Moreno F, Petrie A. Mean annual attachment, bone level, and tooth loss: A systematic review. J Periodontol. 2018 Jun;89 Suppl 1:S120-S139.

87. Darcey J, Ashley M. See you in three months! The rationale for the three monthly periodontal recall interval: a risk based approach. Br Dent J. 2011 Oct 21;211(8):379-85.

88. Carreiro ADFP, Guerra CMF, Moraes SLDD, Farias Neto A, Torres ÉMD, Almeida EOD. The use of a magnetic attachment in a removable partial denture of a patient with periodontal tissue loss. Int J Dent, Recife. 2009;8(4):215-219.

89. Chung KH, Chung CY, Cagna DR, Cronin RJ Jr. Retention characteristics of attachment systems for implant overdentures. J Prosthodont. 2004 Dec;13(4):221-6.

90. MORRIS ML. The position of the margin of the gingiva. Oral Surg Oral Med Oral Pathol. 1958 Sep;11(9):969-84.

91. Robbins JW. Periodontal considerations in the overdenture patient. J Prosthet Dent. 1981 Dec;46(6):596-601.

92. Morrow RM, Powell JM, Jameson WS, Jewson LG, Rudd KD. Tooth-supported complete dentures: description and clinical evaluation of a simplified technique. J Prosthet Dent. 1969 Oct;22(4):415-24.

93. Fenton AH, Hahn N. Tissue response to overdenture therapy. J Prosthet Dent. 1978 Nov;40(5):492-8.

94. Davis RK, Renner RP, Antos EW, Schlissel ER, Baer PN. A two-year longitudinal study of the periodontal health status of overdenture patients. J Prosthet Dent 1981;45:358-63.

95. Toolson BL, Smith DE, Phillips C. A 2-year longitudinal study of overdenture patients part II: assessment of the periodontal health of the overdenture abutments. J Prosthet Dent 1982;47:4-11.

96. Toolson BL, Smith DE. A five-year longitudinal study of patients treated with overdentures. J Prosthet Dent 1983;49:750-6.

97. Graser GN, Caton JG. Influence of overdenture abutment tooth contour on the periodontium: a preliminary report. $\mathrm{J}$ Prosthet Dent. 1983 Feb;49(2):173-7.

98. Kawamoto S, Hamamura S, Kawahara H, Nishi Y, Nagaoka E. Use of a magnetic attachment to retain an obturator prosthesis for an osseous defect. J Prosthodont. 2009 Jun;18(4):359-62.

99. Scherer MD, McGlumphy EA, Seghi RR, Campagni WV. Comparison of retention and stability of implant-retained overdentures based upon implant number and distribution. Int J Oral Maxillofac Implants. 2013 Nov-Dec;28(6):1619-28.

100. Scherer MD, McGlumphy EA, Seghi RR, Campagni WV. Comparison of retention and stability of two implant-retained overdentures based on implant location. J Prosthet Dent. 2014 Sep;112(3):515-21.

101.Ceruti P, Bryant SR, Lee JH, MacEntee MI. Magnet-retained implant-supported overdentures: review and 1-year clinical report. J Can Dent Assoc. 2010;76:a52. 